\title{
Obituary Biography of Albert Weissman
}

Neuropsychopharmacology (2013) 38, 2728; doi: I0.1038/npp.2013.268

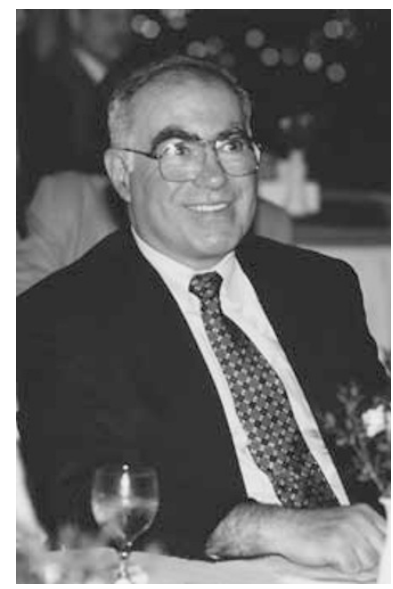

Albert Weissman, of Noank, Connecticut, a retired veteran of Pfizer's Central Nervous System research team, died 11 July after a 20-year battle with Parkinson's disease and prostate cancer. He was 79 years old.

Dr Weissman, who retired in 1995 from Pfizer's Central Research facility in Groton, was for many years the manager of the neurobehavioral, biochemical, and neurological testing groups during the development phases of several important drugs, including Zoloft, Navane, Quantril, and Sinequan. He was also known for his many basic studies and scholarly reviews in the field of neuropsychopharmacology. His total number of scholarly publications exceeded 100 .

Dr Weissman and Dr B Kenneth Koe of Gales Ferry, Connecticut, now also retired from Pfizer, were co-authors in 1966 of two landmark scientific papers, one describing the mechanism of action of amphetamine, and the other identifying PCPA (parachlorophenylaniline), a new drug tool that was vital for understanding the role of the neurotransmitter serotonin in brain function. Both papers became 'Citation Classics,' meaning that they were among the most cited scientific research reports of all time.

Albert Weissman was born 1 August 1933, in the Bronx, NY, the son of Philip and Sophie Weissman. He attended New York City elementary schools and the Bronx High School of Science, from which he graduated in 1950. His undergraduate college education was at the NYU Washington Heights Campus, where in 1954 he received his A.B. in physiological psychology. He received his MS (1955) and PhD (1958) in physiological psychology from
Columbia University. His entire professional career was with Pfizer.

In 2005, Dr Weissman, along with four colleagues from Pfizer, received the American Chemical Society Award for Team Innovation, honoring their research that culminated in the antidepressant drug Zoloft (sertraline). He was a member of the American Society of Pharmacology and Experimental Therapeutics, the International College of Neuropsychopharmacology, and the American College of Neuropsychopharmacology.

Dr Weissman was an accomplished chess player, and he won the 1953 U.S. Intercollegiate Chess Championship, beating out Arthur Bisguier, an International Grandmaster who was then the US Champion. He also played frequently with other accomplished chess players, including Bobby Fischer, just prior to Fischer's ascent as Grandmaster. In the mid-1960s, Dr Weissman ranked third in the United States in correspondence chess.

He leaves his beloved wife of 37 years, the former Donna Lee Duerr. Shortly after their marriage in 1976, Albert and Donna became avid Scrabble players, competing in many national tournaments, and publishing a monthly newsletter, Letters for Expert Games Players. Albert also maintained a life-long interest in music, especially opera, and he played the role of Tevya in the Pfizer Players' 1972 production of Fiddler on the Roof.

In addition to his wife, Donna, Dr Weissman leaves behind five children: Beth Laura Weissman and her husband, Russell Chevrette, of Portland, Oregon; Julie Ruth Marto, and her husband Ralph, of Medfield, Massachusetts; James Barry Weissman, and his wife, Kyoko, of Bedford, Massachusetts; Ellen Judith Carenza, and her husband, Leon, of Norwich, Connecticut; and Eric Michael Weissman, and his partner, Joseph Probus, of Takoma Park, MD.

He leaves six grandchildren: Lillian and Joseph Marto, Jack and Mary Carenza, and Philip and Alex Weissman. He also leaves his sister, Anne Starr, of Eagan, Minnesota, and his former wife, Elaine Levine, of San Francisco.

The family also wishes to extend heartfelt thanks to the team of caregivers who provided both Albert and Donna excellent care and support during Albert's final years: Cindy, Melida, Anny, Tiffany, Mario, Christina, Sharron, Rosa, and Tricia.

Those who wish to acknowledge Dr Weissman may consider a donation to the Southeastern Connecticut Parkinson's Support Group, care of Mary Ellen Thiboudeau, P.O. Box 718, Old Mystic, CT 06372-9992, or to a charity of the donor's choice.

Eric Weissman E-mail: ericmweissman@gmail.com 